Diabetologia 2, 260-264 (1966)

\title{
Plasma Insulin Levels during Pregnancy, in Obesity and Potential Diabetes*
}

\author{
A.E. LamberT**, J.J. HoET and E. EkxA with the technical assistance of B. Horemaxs
}

Laboratoire de Recherches de la Clinique Médicale, University of Louvain - Belgium

Received June 6, 1966

Summary. The plasma insulin was measured by a radioimmunoassay method in 48 non-pregnant or pregnant women during glucose tolerance test $(100 \mathrm{~g}$ glucose by mouth). Each of these 2 groups included non-obese, nondiabetic women, obese females and potential diabetic patients. The non-obese, non-diabetic, non-pregnant subjects showed mean plasma insulin levels of $25.2,77.2,57.0$, 57.8 and $44.7 \mu \mathrm{U} / \mathrm{ml}$ respectively $0,45,90,135$ and 180 minutes after glucose loading. The obese normoglycemic non pregnant females presented a normal fasting plasma insulin level which reaches $184.7 \mu \mathrm{U} / \mathrm{ml} 45$ minutes after glucose intake. The late pregnancy (7th to 9th month) did not change the plasma insulin observed in the nonobese, non-diabetic and obese women. The non-pregnant females with potential diabetes showed a normal fasting plasma insulin with a maximum of $96.9 \mu \mathrm{U} / \mathrm{ml} 90$ minutes after the beginning of the test. In these patients between the 4 th to the 9 th month of the pregnancy, the maximum of $68.2 \mu \mathrm{U} / \mathrm{ml}$ was only obtained 3 hours after the glucose loading. - The physio-pathological significance of these results is discussed.

Taux d'insuline plasmatique dans la gravidité, dans l'abésité et dans le diabète potentiel.

Résumé. L'insuline plasmatique, mesurée par la méthode radioimmunologique, a été dosée chez 48 femmes non enceintes ou enceintes au cours de l'hyperglycémie provoquée par la prise orale de $100 \mathrm{~g}$ de glucose. Chacun de ces 2 groupes de patientes comprenait des femmes non obèses et non diabétiques, des patientes obèses et des femmes présentant un diabète potentiel. Les patiențes non obèses et non diabétiques présentaient en dohors de la grossesse des taux moyens d'insuline plasmatique de 25.2, $77.2,57.0,57.8$ et $44.7 \mu \mathrm{U} / \mathrm{ml}$ respectivement $0,45,90$, 135 et 180 minutes après la surcharge glucosée. Les patientes obèses normoglycémiques non enceintes présentaient à jeun un taux normal d'insuline plasmatique qui atteignait $184.7 \mu \mathrm{U} / \mathrm{ml}, 45$ minutes après la prise du glucose. La grossesse au $3^{\circ}$ trimestre ne modifiait pas les taux d'insuline plasmatique observés chez les femmes non obèses et non diabétiques et chez les patientes obèses. Les femmes avec un diabète potentiel et non enceintes présentaient à jeun un taux normal d'insuline plasmatique avec un maximum de $96.9 \mu \mathrm{U} / \mathrm{ml} 90$ minutes après le début du test. Au cours des $2^{\circ}$ et $3^{0}$ trimestres de la grossesse chez ces patientes, le maximum de $68.2 \mu \mathrm{U} / \mathrm{ml}$ était seulement atteint 3 heures après la prise du glucose. - L'interprétation physio-pathologique de ces résultats est discutée.

Plasmainsulin bei Fettsucht, latentem Diabetes und Schwangerschaft.

Zusammenfassung. Mit einer radioimmunologischen Methode wurde das Plasmainsulin bei 48 nichtschwangeren oder schwangeren Frauen während eines Glucosetoleranztestes (100 g Glucose per os) untersucht. Jede dieser beiden Gruppen umfaßte nichtfettleibige, nichtdiabetische Frauen, fettleibige Frauen und latentdiabetische (nichtfettleibige) Frauen. Die nichtfettleibigen, nichtdiabetischen, nichtschwangeren Personen zeigten nüchtern und 45,90,135 und 180 Min. nach Glucosebelastung einen mittleren Plasmainsulinspiegel von 25.2, $77.2,57.0,57.8$ und $44.7 \mu \mathrm{E} / \mathrm{ml}$. Die fettleibigen, nichtschwangeren Frauen mit normalen Blutzuckerwerten hatten einen normalen Nüchternplasmainsulinspiegel, der 45 min nach Glucoseaufnahme auf einen Wert von 184.7 $\mu \mathrm{E} / \mathrm{ml}$ anstieg. Bei den nichtfettleibigen, nichtdiabetischen und fettleibigen Frauen kam es im letzten Drittel der Schwangerschaft (7.-9. Monat) nicht zu einer Veränderung des Plasmainsulinspiegels. Die latent diabetischen, nichtschwangeren Frauen zeigten einen normalen Nüchternplasmainsulinspiegel mit einem Maximum von $96.9 \mu \mathrm{E} / \mathrm{ml} 90 \mathrm{Min}$. nach Beginn des Testes. Bei den Patienten mit einer Schwangerschaft zwischen dem 4. und 9. Monat wurde das Maximum des Insulinspiegel von $68.2 \mu \mathrm{E} / \mathrm{ml}$ erst drei Stunden nach der Glucosebelastung erreicht. - Die pathophysiologische Bedeutung dieser Befunde wurde besprochen.
Some recent studies have reported the changes observed in plasma insulin levels, determined by radioimmunoassay, during glucose tolerance tests in pregnancy, obesity and the early stages of diabetes.

Some workers have observed no increase of the circulating insulin levels in preclinical diabetes during oral glucose tolerance tests [8] whereas others have shown delayed increase in the insulin levels $[10,2,18]$. In obese subjects, high plasma insulin levels are

* This study was supported by grants from the Fondation Médicale Reine Elisabeth, the Fonds de la Recherche Scientifique Médicale, the Eli Lilly and Co, Indianapolis and the Cyanamid International, Pearl River N.Y.

** Aspirant of the Fonds National de la Recherche Scientifique - Belgium. Present address: Institut de Biochimie Clinique, University of Geneva, Switzerland. reported by some authors $[7,14,18]$ and not by others [2]. Finally, several workers have demonstrated excessive circulating insulin during normal pregnancy and especially in late pregnancy $[19,3,13,20]$. Such data however have not been confirmed by other authors $[6,5]$.

This divergency in the observed results can be partially attributed to the difference in the assay methods employed and the selection of the subjects studied.

The aim of this report is to analyse and compare by the same radioimmunoassay method the variations observed in the plasma insulin levels during oral glucose tolerance tests in different groups of subjects selected on the basis of comparable criteria. Moreover, to our knowledge, no reports have been published 
concerning the plasma insulin levels of obese or potential diabetic pregnant females.

\section{Material and methods}

Subjects: 48 women were studied. The pregnant females were ambulatory patients on a free diet who were sent by the obstetrical clinic to the clinic of endocrinopathy of the pregnancy. The non-pregnant women were hospitalized for a general check-up and received a normal diet (2000 calories). Each of the two groups included non-obese, non-diabetic subjects, obese subjects and patients with potential diabetes. The nonobese, non-diabetic women showed none of the chosen criteria of diabetes ${ }^{1}$ and had normal weight $( \pm 10 \%)^{2}$.

The overweight of obese females was at least $30 \%$ and obesity was the only abnormality. The remaining subjects were considered as potential diabetics, because they had at least two of the mentioned characteristics $^{1}$. All pregnant women under study were in late pregnancy (from 7 th to 9 th month) excepting the group of potential diabetics who were in their 4th to 9 th month of pregnancy. The mean age, height, weight and fasting blood-sugar for each patient group are reported in the table.

Procedures: The patients were studied during oral GTT. An indwelling needle is placed in the antecubital vein between 8 and $9 \mathrm{a} . \mathrm{m}$. following an overnight fast. The subjects remained in the recumbent position during the test. Venous blood samples for insulin assay and capillary blood for blood-sugar determination ${ }^{3}$ were collected simultaneously before glucose intake and every 45 minutes during the 3 following hours. The blood collected on EDTA for insulin assay was immediately centrifuged and the plasma stored at $-10^{\circ} \mathrm{C}$ till the moment of assay.

Radioimmunoassay of insulin: The plasma insulin levels were assayed by the technique of YaLow and Berson [22]. This method was preferred because the chances of error due to non-specific inhibitors, as mentioned in the technique of two antibodies system $[11,17,15]$, is avoided. The original technique was slightly modified in our laboratory as follows:

$5 \mu \mathrm{g}$ of bovine or porcine insulin 10 times recrystallized $(24.8 \mathrm{IU} / \mathrm{mg})^{4}$ was iodinated with $5 \mathrm{mC}$ of iodine-

1 Diabetic parents or children; one or more children with a birthweight exceeding $4 \mathrm{~kg}$; an abnormal GTT (glucose tolerance test: $100 \mathrm{~g}$ glucose by mouth) with at least 2 blood-sugar values higher than the upper limit of the normals and a fasting level remaining under $130 \mathrm{mg} /$ $100 \mathrm{ml}$. Normal GTT: Blood-sugar not exceeding 100, $180,140,110$ and $110 \mathrm{mg} / 100 \mathrm{ml}$ at $0,45,90,135$ and 180 minutes respectively after glucose intake.

2 Tables of "Build and Blood Pressure Study" Society of Actuaries Ed. Chicago 1959. A weight increase of $1.5 \%$ l month between the 3 th and 9 th month of pregnancy was considered as normal.

3 The blood-sugar was measured by means of the Auto-Analyser Technicon according to the modified technique of HoFFMAN [12].

${ }^{4}$ Obtained by courtesy of Dr. J. SoHLICHTKRULL, Novo Research Institute, Copenhagen, Denmark.
${ }^{131} \mathrm{I}$ according to the technique reported by GREENwoop et al. [9]. For 10 successive iodination procedures a mean specific activity of $450 \mathrm{mC} / \mathrm{mg}$ was obtained (1 atom of iodine-131//molecule of insulin). After purification [1] the insulin- ${ }^{131}$ I contained a maximum of $7 \%$ of radioactive impurities. The same batches of insulin were utilized to produce antibodies in guineapigs after emulsifying in the complete FrEUND's adjuvant.

These guinea-pigs received 5 weekly subcutaneous injections of 4 to 12 IU of insulin which have been repeated a year later. The binding capacity of these antiinsulin sera ranged from 1 to 3 IU of human insulin $/ \mathrm{ml}$. Antibodies with a binding constant possessing high affinity towards human insulin have the advantage of increasing the sensitivity of the assay by giving a steep initial slope to the standard curve. Human insulin twice recrystallized $(23.8 \mathrm{IU} / \mathrm{mg})^{4}$ was used as the standard. The insulin-antibody mixtures were incubated for 4 days at $4^{\circ} \mathrm{C}$ and free insulin.- ${ }^{131} \mathrm{I}$ was separated from antibody-bound insulin- ${ }^{131} \mathbf{I}$ by chromatoelectrophoresis on Whatman $3 \mathrm{MC}$ paper. The radioactivity of the strips was measured by an automatic scanogram. All determinations were done in duplicate. To ascertain homogeneous results, the duplicate determinations with more than $7 \%$ of difference were discarded and measured again in a next assay. The sensitivity of our method has been reported previously [16]. The results of a typical recovery experiment are shown in Fig. 1. Five different concentrations of human insulin ranging from 25 to $500 \mu \mathrm{U} / \mathrm{ml}$. were added to a plasma sample containing $22 \mu \mathrm{U} / \mathrm{ml}$ of endogenous insulin. The recovery for all the concentrations studied was satisfactory.

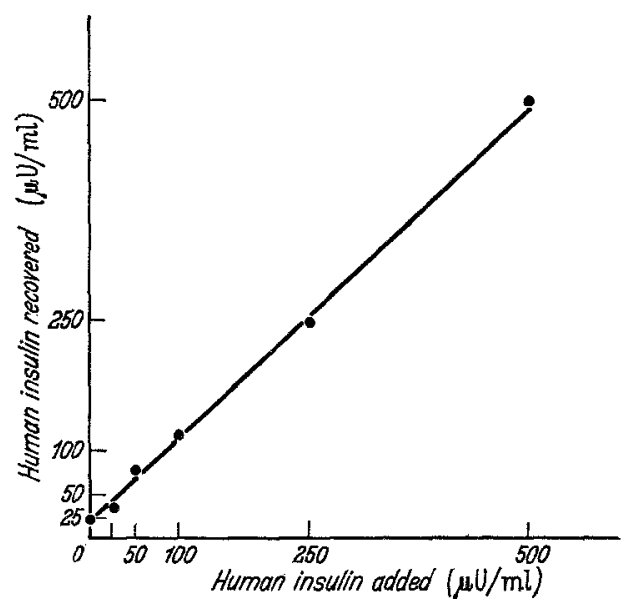

Fig. 1. Recovery experiment after addition of human insulin (concentrations ranging from 25 to $500 \mu \mathrm{U} / \mathrm{ml}$ ) to a plasma containing $22 \mu \mathrm{U} / \mathrm{mI}$ of endogenous insulin

\section{Results}

The results are shown in Fig. 2. The non-pregnant females with potential diabetes showed significantly higher levels of blood-sugar at 90 and 135 minutes after glucose intake than in those of the non-obese, non- 
diabetic women. Whereas, in the group of obese nonpregnant subjects, the blood-sugar remained normal throughout the experiment. During pregnancy, the obese patients and the females with potential diabetes showed higher blood--sugar levels than the non-obese, non-diabetic subjects at 135 minutes after glucose loading.

Non-pregnant obese women had normal fasting insulin level but this level became considerably higher at the 45 th minute reaching $184.7 \mu \mathrm{U} / \mathrm{ml}$ and decreased slowly to $119.9 \mu \mathrm{U} / \mathrm{ml}$ at the 135 th minute. The plasma non-obese, non-diabetic and in the obese patients. From these results, it would thus appear that the plasma insulin levels observed in non-obese, non-diabetic women and in obese subjects were not modified during late pregnancy. The insulin secretion after glucose stimulation seemed to be delayed in subjects with potential diabetes, especially during pregnancy.

\section{Discussion}

The sharp increase of plasma immunoreactive insulin after a glucose load in the non-obese, non-dia-

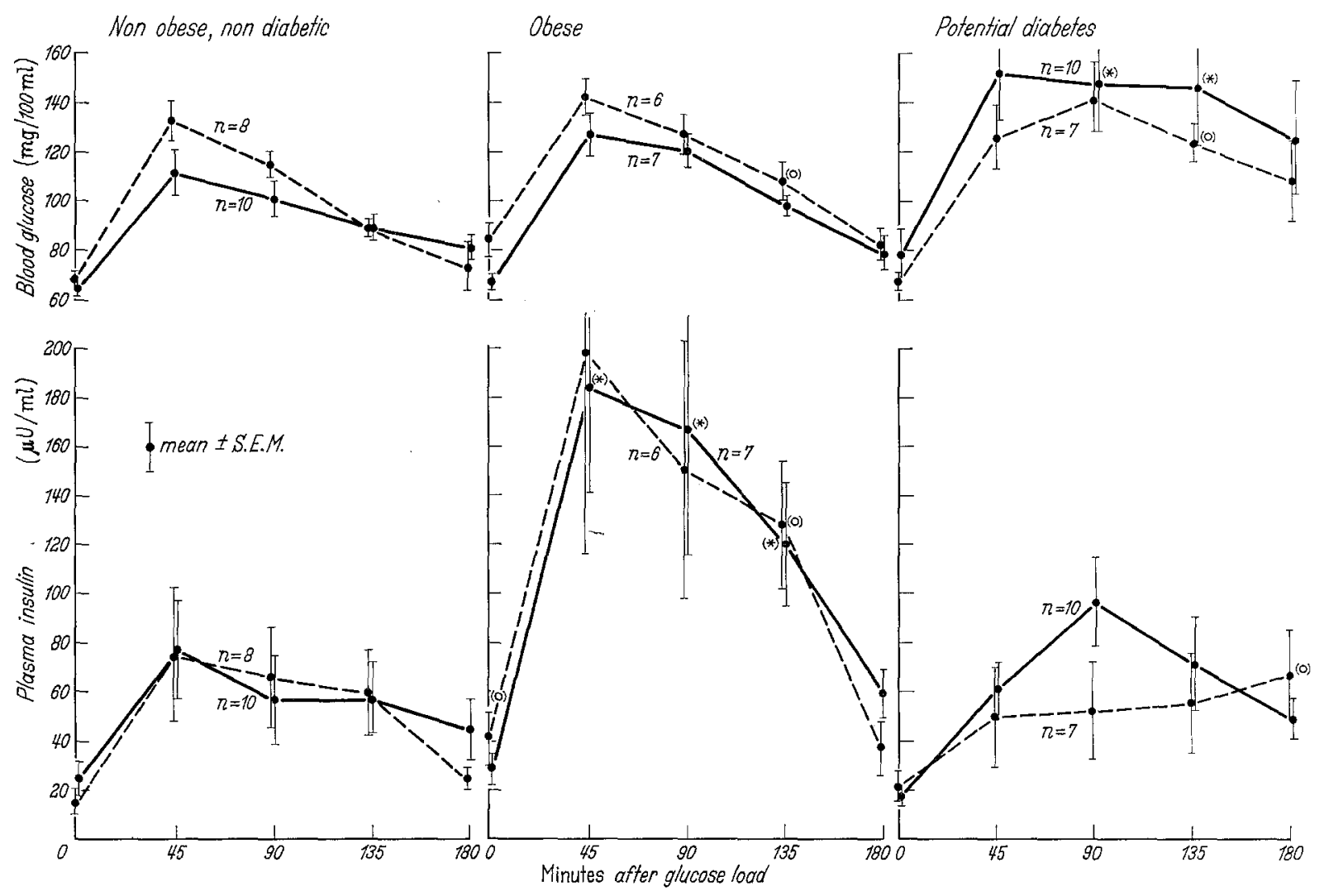

Fig. 2. Blood-glucose and plasma insulin levels during oral glucose tolerance test *) Statistical significance $(p<.05)$ of the comparison with the non-obese, non-diabetic, non-pregnant females. -) Statistical significance $(p<.05)$ of the comparison with the non-obese, non-diabetic, pregnant females.

insulin levels of non-pregnant women with potential diabetes were about the same as in the non obese, non diabetic, non pregnant subjects, although a higher peak level of $96.9 \mu \mathrm{U} / \mathrm{ml}$ (but statistically not significative) was attained at the 90 th minute.

During pregnancy, obese patients had a plasma insulin, already elevated with fasting, which attained a maximum of $198.2 \mu \mathrm{U} / \mathrm{ml}$ at the $45 \mathrm{th}$ minute, and remained high till 135 minutes after glucose loading. The insulin level of pregnant women with potential diabetes increased slowly after glucose intake to reach a maximal level of $68.2 \mu \mathrm{U} / \mathrm{ml}$ after 3 hours. In the potential diabetics, the insulin levels at 180 minutes did not return to fasting values; it did, however, in the betic females studied confirms the data that have appeared since the original observation of YALOW and Berson [22], and agree with the classical concept of glucose-insulin homeostasis.

Our observations showing similar plasma insulin levels in non-obese, non-diabetic, pregnant or nonpregnant women are different from those of SPELLACY and GoETz [19] and of BLEICHER et al. [3], who have demonstrated after intravenous glucose load, during normal late pregnancy, high plasma insulin levels and equal or slightly lower blood-sugar values than those observed in these subjects during post-partum. SPELLACY et al. [20, 21] have also found in normal females between the 13 th and 15 th week of pregnancy 
a normal plasma insulin level and an increased level in mid-pregnancy. It must be said, however, that the mode of glucose administration was different, and it is known that glucose absorption by the gut may be modified during pregnancy [4]. However, KaLkmoFF et al. [13] have observed that normal pregnancy may be associated with elevated insulin levels (as compared with post-partum levels in the same subjects) after glucose administration even by the oral route. In fact, GEstaldi and Crosignani [6] and Crosignani [5], who employed the immunoassay of ARquilla and StaviTskx, failed to observe any difference between the plasma insulin levels of non-pregnant and pregnant normal women after oral glucose load. That pregnancy does not change the plasma insulin level is confirmed by our data in obese subjects. no obvious factor has been demonstrated to explain it and we can only state that the as yet unknown factor which, besides the blood-sugar, induced the high circulating levels of insulin in our obese subjects subsists during late pregnancy.

The plasma insulin of the potential diabetic females so far studied was characterized especially by a delayed peak value after glucose intake, which was attained at the 90th minute in non-pregnant females and only at the 180th minute during pregnancy. This is in accordance with the data of several authors. HaLes [10] observed in 3 latent diabetics after $50 \mathrm{~g}$ oral glucose loading, slightly elevated and sustained insulin levels up to the 60 th minute. In 10 of the patients ( 7 obese and 3 non-obese) studied (under similar conditions, SAMoLs [18] has shown a rise and a shift of the peak of

Table. Age, height, weight and fasting blood-sugar of women under study (mean \pm S.E.M.)

\begin{tabular}{|c|c|c|c|c|c|c|}
\hline & & $\begin{array}{l}\text { Age } \\
\text { (years) }\end{array}$ & $\begin{array}{l}\text { Height } \\
(\mathrm{cm})\end{array}$ & $\begin{array}{l}\text { Weight } \\
(\mathrm{kg})\end{array}$ & $\%$ Overweight & $\begin{array}{l}\text { Fasting blood- } \\
\text { sugar (mg/100 } \\
\text { ml) }\end{array}$ \\
\hline \multirow{2}{*}{$\begin{array}{l}\text { Non-obese, non- } \\
\text { diabetic }\end{array}$} & \multirow{2}{*}{$\begin{array}{l}\text { Non- } \\
\text { pregnant } \\
\text { pregnant }\end{array}$} & $34.5 \pm 3.6$ & $161.9 \pm 1.4$ & $62.5 \pm 2.2$ & 5.2 & $65 \pm 3$ \\
\hline & & $28.3 \pm 2.7$ & $160.6 \pm 0.6$ & $65.6 \pm 3.6$ & 7.2 & $69 \pm 3$ \\
\hline \multirow[t]{2}{*}{ Obese } & \multirow{2}{*}{$\begin{array}{l}\text { Non- } \\
\text { pregnant } \\
\text { pregnant }\end{array}$} & $27.8 \pm 2.6$ & $160.8 \pm 2.0$ & $87.7 \pm 7.7$ & 57.0 & $67 \pm 3$ \\
\hline & & $32.0 \pm 3.2$ & $159.6 \pm 1.9$ & $85.8 \pm 2.1$ & 38.9 & $84 \pm 7$ \\
\hline \multirow{2}{*}{$\begin{array}{l}\text { Potential } \\
\text { diabetic }\end{array}$} & \multirow{2}{*}{$\begin{array}{l}\text { Non- } \\
\text { pregnant } \\
\text { pregnant }\end{array}$} & $41.9 \pm 2.9$ & $158.7 \pm 2.5$ & $73.6 \pm 5.8$ & 21.7 & $79 \pm 9$ \\
\hline & & $33.0 \pm 2.6$ & $156.5 \pm 1.7$ & $69.3 \pm 3.9$ & 17.9 & 68 士 3 \\
\hline
\end{tabular}

In non-pregnant and pregnant obese females, the plasma insulin concentration had risen rapidly by 45 minutes after glucose intake although the blood-sugar values were similar to those of non-obese, non-diabetic subjects. These observations confirm the data of KARAM et al. [14] after intravenous glucose load and that of GRoDsky et al. [7] and of SAMOLS [18] after oral administration of glucose. Bersor and YALOW [2] have however observed no excessive insulin concentration in very obese subjects (more than $30 \%$ overweight) with normal blood-sugar following the administration of $100 \mathrm{~g}$ glucose by mouth. These authors have observed high insulin levels only in obese subjects with "impaired glucose tolerance". However, the blood-sugar criteria chosen for this last group (peak blood-sugar: $160-180 \mathrm{mg} / 100 \mathrm{ml}$, and 2 hours after glucose administration blood-sugar of more than 120 $\mathrm{mg} / 100 \mathrm{ml}$ ) range their subjects at the upper limit of our group of non-diabetic subjects. It is therefore concluded that obese non-pregnant or pregnant women, without tendency to abnormal GTT, have an early higher plasma insulin level, as if a brisk increased. insulin release occured in response to a glucose load. These subjects manifested a resistance to their circulating insulin because higher plasma insulin levels were not followed by lower blood-sugar values. In spite of many data about this insulin resistance during obesity, the circulating insulin. In 18 non-obese patients with "impaired glucose tolerance", Berson and YALOW [2] founded similar concentrations of plasma insulin as in normal subjects but the peak was delayed till the 2 nd hour.

Finally, Grodsky et al. [8] studying subjects with only a family history of diabetes did not observe any modifications in the plasma insulin when compared. with the controls. The modifications observed in the plasma insulin levels during the preclinical stage of diabetes could not yet be explained. However, the patients with potential diabetes showed a delayed glucose tolerance and a loss in the pancreatic ability to produce promptly insulin in response to glucose. It thus appears that the early changes in glucose tolerance are associated with a delayed peak in the plasma insulin levels. Although a rigourous interpretation of these results cannot be made because of the wide diversity in the individual results, radioimmunoassay of plasma insulin during GTT in the present study throws some light on the modifications in the regulative mechanism of insulin secretion.

From our results we may conclude that pregnancy in non-obese, non-diabetic women does not modify the plasma insulin levels after oral glucose load and therefore, for them, seems here not to be a trigger mechanism for diabetes. The glucose-insulin relationship in females 
with potential diabetes is abnormal and remains disordered during pregnancy, which, as an aggravating factor, may perpetuate the concealed glucose intolerance. The obesity in non-pregnant or pregnant women with normal GTT is characterized by an early enhanced insulin response implicating a resistance to insulin which may also be an initiating mechanism for diabetes.

Acknowledgments. We gratefully acknowledge the stimulating criticism of Dr. R. DE HeRToGH.

Addendum. Since the submission of this manuscript, a monograph appeared written by P. VAGUE and entitled: "L'insulinémie dans le diabète et les obésités". Imprimerie Générale de Provence, 16, rue des Convalescents, Marseille, 1966.

\section{References}

[1] Berson, S.A., and R.S. Yatow: Preparation and purification of human insulin-131 I. Binding to human insulin antibodies. J. clin. Invest. 40, 1803-1808 (1961).

[2] - - Some current controversies in diabetes research. Diabetes 14, 549-572(1965).

[3] BLeicher, S.J., J.B. O'Sulitivan and N. Freinkel: Carbohydrate metabolism in pregnancy. 5. The interrelations of glucose, insulin and free fatty acids in late pregnancy and post-partum. New Engl. J. Med. 271, 866-872 (1964).

[4] BURT, R.L.: Glucose tolerance in pregnancy. Diabetes 11, 227-228 (1962).

[5] Crosignani, P.G.: Determinazione immunologica del'insulina plasmatica in donne gravide. Ann. Ostet. Ginec. 82, 258-262 (1960).

[6] Geistaldi, A., and P.G. Crosignani: Modificazioni del'insulinomia in gravidanza dopo carico orale di glucosio. Ann. Ostet. Ginee. 81, 1171 - 1178 (1959).

[7] Grodsky, G.M., J.H. Karam, F.C. Pavlatos and P.H. ForshaM: Reduction by phenformin of excessive insulin levels after glucose loading in obese and diabetic subjects. Metabolism 12, 278-286 (1963).

[8] _ _ _ - Serum insulin response to glucose in prediabetic subjects. Lancet 1965 I, 290-291.

[9] Greenwood, F.C., W.M. HunTer and J.S. GLover: The preparation of ${ }^{131}$ C-labelled human. growth hormone of high specific radioactivity. Biochem. J. $89,114-123(1963)$.

[10] Haims, C.N.: Plasma insulin in diabetes. In Ciba Foundation Colloquia on Endocrinology, vol. 15, p. $140(1964)$.

[11] - , and P.J. RANDLE: Immunoassay of insulin with insulin-antibody precipitate. Biochem. J. 88, 137146 (1963).

[12] Hofrman, W.S.: A rapid photoelectric method for the determination of glucose in blood and urine. $J$. biol. Chem. 120, 51-53 (1937).

[13] KatkhofF, R., D.S. SchalCh, J.I. WALKER, P. BeCK, D.M. KIPNIS and W.H. DavghadaY: Diabetogenic factors associated with pregnancy. Trans. Ass. Amer. Phycns 77, $270-279$ (1964).

[14] Karam, J.H., G.M. Grodsky and P.H. Forsham: Excessive insulin response to glucose in obese subjects as measured by immunochemical assay. Diabetes 12, $197-204(1963)$.

[15] KuzuYA, T., and E. Samols: The plasma insulin "inhibitor" and immunoprecipitation assay. Metabolism 13, 493-495 (1964).

[16] LamberT, A.E., and J.J. Howt: Diurnal pattern of plasma insulin concentration in the human. Diabetologia 2, 69-71 (1966).

[17] Morgan, C.R., R.L. Soresson and A. Lazarow: Studies of an inhibitor of the two antibody immunoassay system. Diabetes $13,1-5$ (1964).

[18] Samols, E.: Immunochemical aspects of insulin. In Proceedings of the 5th Congress of the International Diabetes Federation, Toronto, 1964 ; Excerpta Medica Foundation: On the nature and treatment of diabetes, p. 227 (1965).

[19] Spellacy, W.N., and F.C. Goetz: Plasma insulin in normal late pregnancy. New Engl. J. Med. 268, 988991 (1963).

[20] - - B.Z. Grenenberg and J. Elus: Plasma insulin in normal midpregnancy. Amer. J. Obstet. Gynec. 92, $11-15(1965)$.

[21] - - - Plasma insulin in normal "early" pregnancy. Obstet. and Gynec. 25, 862-865 (1965).

[22] YaLOw, R.S., and S.A. BERson: Immunoassay of endogenous plasma insulin in man. J. clin. Invest. 39, $1157-1175$ (1960).

Dr. Joseph J. HowT

Laboratoire de Recherches de la Clinique Médicale Hôpital Saint-Pierre Louvain, Belgium 